\title{
ANALISIS JARINGAN KOMUNIKASI DALAM PENCEGAHAN KEBAKARAN LAHAN DI DESA TANJUNG PERANAP KECAMATAN TEBING TINGgI BARAT KABUPATEN KEPULAUAN MERANTI
}

\author{
Deby Kurnia ${ }^{1}$, Yulia Andriani ${ }^{2}$, Roza Yulida ${ }^{3}$, Rosnita ${ }^{4}$ \\ 1,2,3,4 Jurusan Agribisnis Fakultas Pertanian Universitas Riau, Pekanbaru \\ Email: deby.kurnia@lecturer.unri.ac.id (korespondensi)
}

\begin{abstract}
The issue of land fires is undeniably a high frequency discussion in Indonesia. Various prevention efforts have been carried out by the community independently, the government, and in collaboration with various related elements. It is also carried out at various levels of government from the central government to the village government level. This study aims to (1) find out community leaders who play a role in efforts to prevent land fires in Tanjung Peranap Village, (2) analyze the role of community leaders both individually and in groups in efforts to prevent land fires (3) Analyze communication networks for actors who play a role in an effort to prevent land fires in Tanjung Peranap Village. The main source of information was obtained from in-depth interviews with respondents who were deemed to meet the research requirements, and then analyzed using descriptive methods. There are several central figures who play a role in controlling land fires including village government leaders (Head and Village Secretary), Head of BPD, agricultural extension workers (PPL) as sources of information in learning, as well as youth leaders and traditional leaders. Communication networks tend to be in the form of a wheel pattern with several figures acting as central or sources of information. The role of community leaders is considered quite strong, including in efforts to establish a Fire Care Society, socialize government activities in efforts to prevent land fires and convey the interests of the community in an effort to maintain a balance between efforts to increase income and efforts to prevent land fires.
\end{abstract}

Keywords: land fires, sago, MPA, opinion leaders.

\begin{abstract}
Abstrak
Isu kebakaran lahan tidak dipungkiri lagi telah menjadi pembahasan dengan frekuensi tinggi di Indonesia. Berbagai upaya pencegahan telah dilakukan baik oleh masyarakat secara swadaya, pemerintah, maupun kolaborasi berbagai elemen terkait. Dilakukan juga pada berbagai tingkat pemerintahan dari pemerintah pusat sampai kepada level pemerintahan desa. Penelitian ini bertujuan untuk (1) mengetahui tokoh masyarakat yang berperan dalam upaya pencegahan kebakaran lahan di Desa Tanjung Peranap, (2) Menganalisis peran tokoh masyarakat baik secara individu maupun secara berkelompok dalam upaya pencegahan kebakaran lahan (3) Menganalisis jaringan komunikasi pada aktor yang berperan dalam upaya pencegahan kebakaran lahan di Desa Tanjung Peranap. Sumber informasi utama diperoleh dari wawancara mendalam kepada responden yang dianggap memenuhi persyaratan penelitian, dan selanjutnya dianalisis dengan metode deskriptif. Terdapat beberapa tokoh central yang berperan dalam pengendalian kebakaran lahan diantaranya pimpinan pemerintahan desa (Kepala dan Sekretaris Desa), Ketua BPD, penyuluh pertanian lapangan sebagai sumber informasi dalam pembelajaran, serta tokoh pemuda dan tokoh adat. Jaringan komunikasi cenderung berbentuk pola roda dengan beberapa tokoh berperan sebagai central atau sumber informasi. Peran tokoh masyarakat dinilai cukup kuat diantaranya dalam upaya pembentukan Masyarakat Peduli Api, sosialisasi kegiatan pemerintah dalam upaya pencegahan kebakaran lahan dan menyampaikan kepentingan masyarakat dalam upaya menjaga keseimbangan antara usaha peningkatan pendapatan dengan upaya pencegahan kebakaran lahan.
\end{abstract}

Kata Kunci : kebakaran lahan, sagu, Masyarakat peduli api (MPA), pemuka pendapat.

\section{Pendahuluan}

Dampak kebakaran hutan telah menjadi pembahasan yang berpekepanjangan di
Indonesia. Berbagai upaya telah dilakukan baik dari sisi pembangunan infrastuktur sampai kepada pengembangan 
kelembagaan pada komunitas masyarakat. Kolaborasi berbagai komponen pada beberapa level pemerintahan dengan masyarakat juga telah dilakukan yang didukung oleh usaha swadaya masyarakat itu sendiri. Pendekatan yang dilakukan sejalan dengan hasil penelitian Yulida (2017) di Kabupaten Rokan Hilir yang menyatakan bahwa faktor sosial (tradisi dan budaya masyarakat), dan ekonomi sangat berpengaruh dalam upaya pencegahan dan pengendalaian kebakaran lahan. Dari sisi sosial dan kelembagaan, Syaufina (2017) menyarankan adanya kelompok masyarakat terutama petani sekitar lahan potensi kebakaran untuk saling berintegrasi dalam upaya pencegahan kebakaran lahan

Kejadian Kebakaran terutama di Provinsi Riau tahun 2014 dinilai sama dampaknya dengan kebakaran pada tahun 1997. Ini menjadi salah satu faktor pendorong pemerintah untuk membentuk badan khusus yang menangani restorasi lahan terutama gambut yang kemudian dikenal dengan Badan Restorasi Gambut pada awal 2016, Badan ini dicita-citakan dapat menjadi ujung tombak upaya pemerintah mengendalikan kebakaran hutan dan lahan. Selain itu, tentu diharapkan dapat bersinergi dengan masyarakat yang memiliki peran besar berkaitan dengan pengendalian kebakaran lahan. Untuk itu, tujuan khusus dari penelitian ini adalah:

a. Mengidentifikasi berbagi upaya dalam bentuk kegiatan atau program yang pernah dan sedang dilakukan dalam pencegahan kebakaran lahan di Desa Tanjung Peranap

b. Menganalisis jaringan komunikasi dalam kegiatan atau yang pernah dan sedang dilakukan dalam pencegahan kebakaran lahan di Desa Tanjung Peranap

c. Menganalisis peran pemuka masyarakat dalam kegiatan atau yang pernah dan sedang dilakukan dalam pencegahan kebakaran lahan di Desa Tanjung Peranap

\section{METODE PENELITIAN}

Rangkaian Penelitian dilakukan di Desa Tanjung Peranap sebagai salah satu desa di Kecamatan Tebing Tinggi Barat Kabupaten Kepulauan Meranti yang memilki lahan terutama gambut yang cukup luas. Penelitian dimulai dari tahapan pra survey, survey lapangan, analisis data dan pelaporan.
Metode survey menjadi bagian utama dari penelitian yakni dengan melaksanakan pengamatan dan wawancara langsung kepada responden yang sesuai dengan kriteria penelitian. Adapun kriteria responden antara lain:

a. Berbagai pihak yang diduga memiliki peran besar dalam upaya pencegahan kebakaran hutan, dalam hal ini yang termasuk adalah Anggota Masyarakat Peduli Api (MPA), Kepala dan Sekretaris Desa, Tokoh Pemuda, Badan Permusyawaratan Desa (BPD), dan Lembaga Ketahanan Masyarakat Desa

b. Masyarakat yang terdaftar sebagai warga Desa Tanjung Peranap Kecamatan Tebing Tinggi Barat Kabupaten Kepulauan Meranti

Sumber data terdiri dari 2 bagian utama yakni (1) data primer yang didapatkan langsung dari responden melalui proses wawancara mendalam dengan kuesioner terstruktur yang terkait topik penelitian. Selanjutnya data sekunder diperoleh dari berbagai laporan dana catatan program yang terdapat di Kantor Kepala Desa.

Sesuai dengan kebutuhan penelitian, wawancara mendalam terutama terkait dengan analisis peran pemuka masyarakat dilakukan terhadap beberapa tokoh masayarakat yang diduga memeliki peran lebih dibanding tokoh atau aktor lainnya.

Analisis data menggunakan metode deskriptif yang disesuaikan dengan tahapan pencapaian tujuan penelitian.

\section{PEMBAHASAN}

3.1. Kebakaran di Desa Tanjung Peranap Kebakaran di Desa Tanjung Peranap terjadi sejak pada tahun 2013. Kebakaran hutan dan Lahan terjadi pertama kali sangat besar dengan luas kebakaran mencapai 60 ha. Melihat kondisi api yang tidak bisa dikendalikan Iagi, Kepala Desa Tanjung Peranap membentuk sebuah komunitas kebakaran hutan dan lahan. Komunitas ini dinamakan Komunitas Masyarakat Peduli Api (MPA). Komunitas Masyarakat Peduli Api ini di bentuk untuk penanggulangan kebakaran lahan di Desa Tanjung Peranap. Sejak dibentuknya komunitas Masyarakat Peduli Api ini kebakaran di Desa Tanjung Peranap hampir tidak terjadi kebakaran yang luas. Komunitas Masyarakat Peduli Api ini diwajibkan dari Pemerintahan Kepulauan Meranti untuk Penanggulangan kebakaran hutan dan lahan. 


\subsection{Program Kegiatan Tanjung Peranap}

Upaya penanggulangan kebakaran lahan di Desa Tanjung peranap dengan dibuat beberapa program. Pada tahun 2016 masyarakat tidak difokuskan pada pertanian. Masyarakat hanya difokuskan pada budidaya dan pengolahan sagu hal ini untuk menangulangi kebakaran di Desa Tanjung Peranap. Selanjutnya pada tahun Mei 2016 adanya program pengembangan pertanian di Desa Tanjung Peranap. Program ini dapat memberdayakan lahan lahan tidur menjadi lahan pertanian yang produktif. Lahan yang digunakan dalam program ini adalah $200 \mathrm{Ha}$ dan dibentuknya Kelompok Tani. Melalui program ini masyarakat difokuskan pada pertanian seperti menanam Kangkung, bayam dan Cabe. Selanjutkan kelompok tani ini mendapatkan bantuan jagung, kedelai, dolomit. Program pertanian ini berhasil sehingga bisa melakukan panen raya cabe di Desa Tanjung Peranap.

Pada tahun 2017 program terdapat program penanggulangan kebakaran hutan dan lahan dengan adanya bantuan Restorasi gambut melaui pilot project pembangunan desa berbasis sagu yang di bina oleh Prof. Bintaro dari Institute Pertanian Bogor (IPB). Pilot project berfokus dalam pengembangan usaha pertanian yang terintegrasi dan aksi nyata di masyarakat. Komoditas utama dalam pengembanga berkaitan degan tanaman sagu. Pilot project ini mengembangkan sagu dengan disandingkan dengan tumpang sari seperti tumpang sari ternak ruminansia terutama sapi, itik, lele, tanaman hortikultura semisal cabe dan tanaman lainnya yang sesuai dengan karakteristik tanah disekitar lahan gambut. Program ini dilaksanakan bersamaan dengan Mahasiswa Institut Pertanian Bogor (IPB).

Pada tahun 2017 Badan Resortasi Gambut memberikan bantuan sekat kanal di Desa Tanjung Peranap. Daya simpan (retensi) air terutama pada badan kanal dan sekitarnya akan tetap basah dan sulit terbakar dengan adanya sekat kanal. Program ini juga di ikuti dengan penyuluhan rutin tentang pengolahan lahan tanpa bakar. $\mathrm{Hal}$ ini menyadarkan masyarakat yang awalnya sudah biasa membakar lahan dan mengolah tanpa membakar tidak akan produktif. Cara pengolahan lahan tanpa membakar yaitu dengan pemberian dolomit yang berdampak kepada peningkatan pengeluaran. Sehingga cara kedua memberatkan masyarakat dan banyak masyarakat yang tidak mau melakukan cara ini. Cara kedua yaitu dengan abu uyung yaitu abu yang berasal dari kilang kilang hasil pembakaran kulit - kulit sagu. Pengambilan abu uyung ke kilang kilang sagu ini tidak dikenakan biaya jika diambil sendiri di kilang kilang sagu. Selanjutnya cara selanjutnya dilakukan dengan cara di Tebas.

Pada tahun 2018 di Desa Tanjung Peranap dalam program pengembangan pertanian di Desa tanjung Peranap kelompok tani kenunduk putih mendapat bantuan dari Dinas ketahanan pangan berupa Jagung, Pakan dan pupuk dalam bentuk uang sebanyak Rp 90.000 Per Hektar sebanyak 30 Ha. Bantuan diberikan kepada kelompok tani untuk tetap melanjutkan pertanian di Desa Tanjung Peranap. Dari program pertanian ini sudah berhasil terbukti dengan adanya tanggapan oleh masyarakat Desa Tanjung Peranap akan tetapi belum semua Masyarakat ikut serta dalam program ini.

Pada Tahun 2018 pemerintah Kabupaten Kepulauan Meranti dan Pemerinah Provinsi Riau bekerjasama meningkatakan kelancaran arus transportasi dengan pembangunan Jalan yang melintas di kawasan Kampung Balak. Usaha tersebut dinikai kuarng tuntas akibat kondisi alam yang tidak mendukung. Pada tahun September 2018 Badan Resortasi Gambut Kembali memberikan bantuan sekat kanal sebanyak 39 sekat kanal di Desa Tanjung Peranap.

\subsection{Analisis Jaringan Komunikasi dalam Penanggulangan Kebakaran Lahan di desa TanjungPeranap}

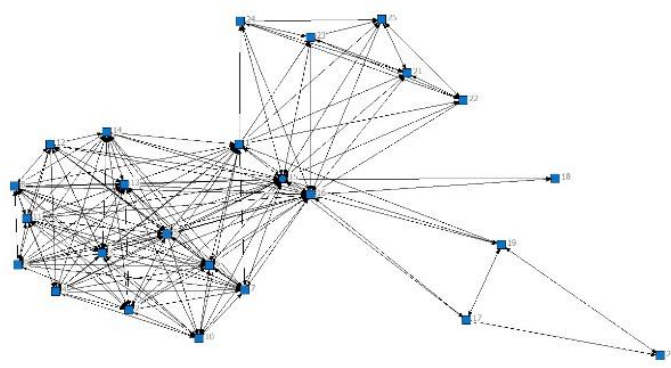

Gambar 1. Jaringan Komunikasi yang terbentuk dalam Pengendalian Kebakaran Lahan di Desa Tanjung Peranap

Aktor-aktor yang terlibat dalam jaringan komunikasi pencegahan kebakaran lahan di DesaTanjun Peranap adalah:

a. Sopian (MPA/Tokoh Masyarakat)

b. Ramli (Bendahara MPA/Tokoh Masyarakat)

c. Erwin (Tokoh Masyarakat)

d. Erzan (Tokoh Masyarakat)

e. Budi (Tokoh Masyarakat)

f. Al Bakri (Tokoh Masyarakat)

g. Antan (Tokoh Masyarakat)

h. Pendi (Tokoh Masyarakat)

i. Pemilik Kilang Sagu 
j. Eriyanto Kilang Sagu

k. Atan Poso (Tokoh Masyarakat)

I. Mudi (MPA/Tokoh Masyarakat)

m. Ijat (Tokoh Masyarakat)

n. Adi (MPA/Tokoh Masyarakat)

o. Edi Junaidi (MPA/Tokoh Masyarakat)

p. Kades

q. Sekdes

r. BPD

s. Petani Sagu

t. Kilang Sagu

u. Joni (Kaur Pemerintahan)

v. TNI

w. Dinas Pemadam Kebakaran'

$\mathrm{X}$. Polres

y. BPBD

z. Satpol PP

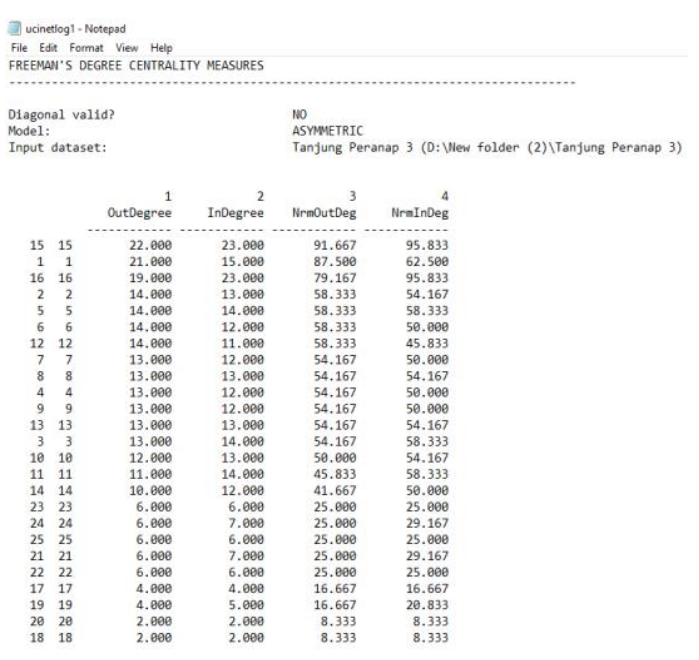

3.4. Peranan Pemuka Pendapat dalam Penanggulangan Kebakaran Lahan di desa Tanjung Peranap

Pemuka masyarakat atau yang sering juga disebut pemuka pendapat adalah orang yang didengarkan pendapatnya, mampu berpengaruh secara formal terhadap sikapsikap atau perilaku nyata dari individuindividu lain, terjadi melalui cara-cara yang diinginkan serta dengan frekuensi yang relatif tinggi atau intensif (Wiryanto, 2004). Nurudin (2010) menambahkan, karakteristik pemuka pendapat umumnya memiliki pendidikan formal, status sosial, ekonomi yang lebih tinggi. Selain itu, pemuka pendapat juga lebih inovatif karena mereka lebih tinggi media exposurenya, lebih mampu berempati karena partisipas sosialnya lebih tinggi dan lebih tinggi kekosmopolitannya. Karakteristik yang demikian membuat para pemuka pendapat bisa mempengaruhi tingkat keberhasilan suatu program. Sejak awal komunikasi pembangunan di Indonesia, pemuka pendapat selalu dilibatkan. Salah satu penelitian yang dilakukan Jaali dkk (2014) menyimpulkan bahwa para pemuka pendapat membantu memelihara kedamaian di tengah konflik horizontal di Ambon. Pemuka pendapat yang dikaji pada penelitian ini adalah aparat desa yang terdiri dari kepala desa, sekretaris desa, ketua badan permusyawaratan desa. Selain aparat desa, yang diwawancarai adalah penyuluh pertanian lapangan, pemuka masyarakat dan Ketua Pemuda. Desa Tanjung Peranap merupakan desa yang juga dikenal dengan sebutan Desa Balak. Luas wilayah desa ini adalah $150 \mathrm{Km}$. Desa ini terdapat tiga dusun yaitu Dusun Bunga Tanjung, Dusun Parit Senin, serta Dusun Parit Laji.

Aparat desa bersama para pemuka pendapat lainnya aktif berkomunikasi dengan masyarakat, khususnya tentang penanggulangan kebakaran lahan. Hampir setiap tahun terjadi kebakaran lahan pada daerah tersebut. Sehingga pada tahun 2013, dibentuklah kelompok Masyarakat Peduli Api (MPA). Sebelum menjalankan tugasnya, kelompok MPA mendapatkan pelatihan tentang cara penanganan kebakaran lahan. Selain itu, kelompok ini juga dibekali perlengkapan pemadaman kebarana dini. Kelompok MPA merupakan gabungan atau kolaborasi antara pemerintah dengan masyarakat setempat dalam hal in warga Desa Tanjung Peranap. Kelompok MPA merupakan hasil kolobaorasi antara Pemerintah Kecamatan Tebing Tinggi Barat dengan Badan Penanggulangan Bencana Daerah (BPBD) Kabupaten Kepulauan Meranti. Pembentukan MPA ini tertuang pada Keputusan Bupati Nomor 22 Tahun 2017 tentang Tim Pembina pencegahan dan penanggulangan kebakaran lahan dan hutan. Kelompok MPA terbentuk dari hasil musyawarah desa yang dikenal dengan rembuk desa. Hasil musyawarah memutuskan

14 (empat belas) warga sebagai perwakilan masyarakat dan berperan dalam pengawasan dan pengendali kebakaran lahan. Dalam kegiatannya, MPA dapat 
langsung berkoordinasi dengan kepala desa. Struktur kelompok MPA terdiri dari ketua yang diamanahkan kepada Bapak Sofyan, untuk bendahara yaitu Pak Ramli dan dibantu oleh (12) dua belas anggota berasal dari unsur yang berbeda yaitu, Pendi, Ijat, Erzanm Budi, Al Bakri, Antan, Eriyanto, Atan Poso, Erwin, Edi Junaidi, Mudi, dan Adi. Range umur anggota MPA berada pada 20 sampai dengan 50 tahun atau masih berada pada usia produktif. Pendekatan MPA untuk pencegahan dan penanggulangan kebakaran lahan ini adalah dengan melibatkan langsung masyarakat meskipun yang tidak tergabung dengan MPA.

Hasil penelitian Yulida (2017) membuktikan di Kabupaten Rokan Hilir bahwa faktor sosial (tradisi dan budaya masyarakat), dan ekonomi sangat berpengaruh dalam upaya pencegahan dan pengendalaian kebakaran lahan. Keterlibatan masyarakat dalam MPA diharapkan dapat meningkatkan efektivitas penanggulangan kebakaran lahan.

Informasi yang diperoleh dari Camat Tebing Tinggi Barat yang menyatakan bahwa faktor manusia menjadi penyebab sebagain besar kebakaran hutan. Masyarakat yang membuka lahan dengan cara membakar dan membuang puntung rokok sembarangan di kawasan hutan. Untuk itu, kelompok MPA bersama dengan aparat desa aktif melakukan sosialisasi dan edukasi terkait kebakaran hutan.

Sosialisasi pencegahan kebakaran lahan turut diupayakan oleh kepala Desa bersama perangkat desa terutama mengenai pentingnya mengolah lahan pertanian tanpa pembakaran. Pendekatan dilakukan baik secara langsung ataupun melalui komunikasi. Kepala desa mendorong masyarakat untuk aktif dan ambil bagian dalam upaya yang disepakati bersama. Selain itu, pimpinan desa lainnya juga terlibat seperti BPD dan Kepala Dusun. Koordinasi rutin dijalankan dengan pihak terkait seperti Pneyuluh pertanian, dan MPA itu sendiri.

\section{KESIMPULAN DAN SARAN}

Upaya pencegahan kebakaran lahan telah dilakukan di Desa Tanjung Peranap dengan melibatkan beberapa tokoh dengan tingkat kepentingan dan bentuk jaringan dominan pola roda. Kesimpulan yang dapat ditarik dari penelitian ini : a. Masyarakat fokus pada pengolahan hasil pertanian terutama dalam hal ini pada komoditi sagu. Di Desa Tanjung Peranap juga dikembangkan pertanian yang terintegrasi melalui Pilot Project. Selanjutnya dalam rangka dalam rangka pemeliharaan kanal, dilakukan upaya pembangunan sekat kanal melalui Badan Restorasi Gambut

b. Jaringan komunikasi yang terbentuk lebih dominan kepada pola roda dengan beberapa tokoh sebagai pusat informasi

c. Peran pemuka masyarakat menjadi faktor penting dalam pencegahan kebakaran lahan, beberapa diantaranya adalah tokoh yang terlibat pada Masyarakat Peduli Api, Perangkat desa, Penyuluh Pertanian Lapangan, dan Badan Permusyawatan Desa. Peran pemuka masyarakat terindentifikasi dari berbagi kegiatan diantaranya terlaksanananya rembuk (rapat) desa sebagai dari tahapan terbentuknya MPA, membantu pemerintah dalam sosialisasi dan pelaksanaan program yang terkiat pencegahan kebakaran lahan, motor penggerak keterlibatan aktif masyarakat dalam upaya pencegahan kebakaran lahan.

\section{DAFTAR PUSTAKA}

[1]. Jaali, dkk. "Peran Pemuka Pendapat (Opinion Leader) Dalam Memelihara Kedamaian di Tengah Konflik Horizontal di Desa Wayame Ambon". KAREBA:Jurnal IImu Komunikasi. Vol.2 No.3 Juli - September 2013

[2]. Syaufina, L. "Peran Strategis Sektor Pertanian Dalam Pengendalian Kebakaran Lahan Gambut". Risalah Kebijakan Pertanian Dan Lingkungan Rumusan Kajian Strategis Bidang Pertanian dan Lingkungan, 1(1), 35-39, 2017

[3]. Wiryanto. "Pengantar Ilmu Komunikasi". Jakarta : PT. Gramedia Widiasarana Indonesia, 2004

[4]. Yulida, R. "Peran Kelompoktani Dan Masyarakat Peduli Api (MPA) Dalam Mengelola Dan Mencegah Kebakaran Lahan di Kecamatan Bukit Batu Kabupaten Bengkalis". Jurnal Agribisnis, 2017 